\title{
INVESTMENT APPRAISAL IN THE PUBLIC SECTOR
}

\author{
R. A. BREALEY \\ I. A. COOPER \\ M. A. HABIB \\ London Business School ${ }^{1}$
}

Recent developments, such as privatization and the private finance initiative, have raised the issue of which assets should be owned by the public sector and whether assets have different values in the public and private sectors. In order to answer these questions, we first note that the allocative considerations that usually motivate government intervention need not require the direct provision of services by the government using government-owned assets. We then argue that the government should own the assets used to provide the services where the private sector fears expropriation by the government, or where ownership confers on the private sector such power as to preclude efficient allocations. Finally, we argue that the discount rate for governments' projects equals the expected return on comparable investments in the capital markets, The government should, however, discount pre-tax cash flows at the pre-tax discount rate, for it receives all tax revenues.

\section{INTRODUCTION}

Governments undertake a variety of activities. They are responsible for setting macroeconomic policy; they seek to promote equity by aiding the poor and the disadvantaged and they provide a variety of services, such as education, health, defence, infrastructure, and police and postal services. Many of these activities involve large investments. For example, the cost of the four-nation Eurofighter programme is expected to be of the order of $£ 38$ billion, that of the proposed trans-European transportation network in the range of $£ 53$ billion.

Recent developments such as privatization and the private finance initiative (PFI) in the United Kingdom have raised the issue of which assets should be owned by the public sector, whether assets have different values in the public and private sectors and how to price assets that are transferred between these two sectors. ${ }^{2}$ The crux of each of these questions is whether investment appraisal in the

\footnotetext{
${ }^{1}$ This paper has benefited from comments by participants at the Oxford Review of Economic Policy seminar, and from discussions with Norman Glass, HM Treasury, and Emily Sims. The views expressed here, however, are those of the authors.

${ }^{2}$ See Paul Grout's article in this issue for a discussion of the PFI.
} 
public sector should differ from that in the private sector. The latter is well understood. The former is the object of the present paper.

The paper consists of two principal sections. After this introduction, in section II, we review the distinctive features of government intervention in the economy. We contrast investment appraisal in the public and private sectors and we note the differing nature of the agency problems involved and the differing intent of the investments contemplated. In particular, we note that government intervention in economic activity is commonly required in the case of public goods or monopolies or in the presence of externalities. Such intervention need not, however, require the direct provision of services by the government using government-owned assets. The government may instead choose to tax, subsidize, or regulate the provision of services by the private sector. It may also choose to provide services directly, using assets it has leased from the private sector. We argue that the direct provision of services by the government is most likely to be justified where the nature and quality of these services are not easily pre-specified or subsequently verified, or where the government would be put at a severe informational disadvantage vis-à-vis private-sector suppliers if it were to entrust these with the provision of the services. We then argue that the government should own the assets used to provide the services where the private sector fears expropriation by the government or where, on the other hand, ownership confers on the private sector such power as to preclude efficient allocations.

In section III, we consider possible criteria for government investment decisions. The commonly used procedure of cost-benefit analysis has its origin in the Hicks-Kaldor criterion that the government should undertake an economic activity if those who would gain from this activity could afford to compensate those who would lose. Although much of the difficulty in applying cost-benefit analysis to a project is related to the difficulty of measuring benefits and costs, such measurement problems arise in all government economic decisions. The characteristic feature of investment decisions is their concern with benefits and costs that arise at different points in time and may be uncertain. We therefore devote our main attention to the rate at which the government should discount benefits and costs that occur in the future and may be risky.

While our discussion is of general applicability, we illustrate many of the issues we consider with aspects of the project appraisal procedures used by the UK government.

\section{THE DISTINCTIVE FEATURES OF GOVERNMENT INTERVENTION IN THE ECONOMY}

\section{(i) Investment Appraisal in the Public and Private Sectors}

Where there are complete and well-functioning capital markets, the managers of private-sector firms will maximize the welfare of shareholders by undertaking all projects that increase shareholder wealth. A project's contribution to shareholder wealth-its net present value (NPV)—is calculated by discounting the project's expected cash flows by the return expected on capital market securities of equivalent risk. Although there is considerable debate about the best model for estimating this expected return, it is generally agreed that investors require a premium for bearing risk. This risk premium takes the form of a higher required return and depends on the project's non-diversifiable (or factor) risk. Of course, the fact that managers can best help shareholders by accepting all positiveNPV projects does not ensure that they will do so. Many of the interesting issues for private-sector firms therefore centre on how managers can be encouraged to act in shareholders' interests and how they can be disciplined when they do not.

There are some obvious parallels between the problems faced by the public and private sectors. Both sectors undertake projects that require making some initial investments and are expected to provide benefits over a number of years. Both sectors must choose between making these investments and returning the cash to be invested to their beneficiaries-the shareholders in the case of private-sector firms, and the citizenry in the case of governments - who can then invest the cash directly in the capital markets or spend it on current consumption. As all parties involved-private-sector firms, the 
government, shareholders, and the citizenry-have access to the same capital markets, the marginal opportunities forgone by making these investmentsthe opportunity cost of these investments-should be the same for both sectors. In neither case can the beneficiaries' wishes be ignored with impunity. Private-sector managers are monitored by boards of directors, who are elected by shareholders. Directors will replace managers if these prove to be incompetent, or run the risk of themselves being replaced. Similarly, citizens in a democracy are provided, through elections, with the regular opportunity to replace incompetent governments. They also elect representatives whose role is to monitor the government. At first blush, then, one might expect the investment criteria that are appropriate for private-sector firms to be fairly similar to those for government. That this need not lead to the same investment appraisal procedures is a consequence of the differing nature of the agency relationships in the public and private sectors, the differing intent of the contemplated investments, and the presence of distortions such as taxes. We examine these in turn.

\section{(ii) Agency Costs in the Public and Private Sectors}

Despite the relative ease with which a government can be replaced in a democracy, the private sector appears to be better than the public sector at handling agency problems. It can consequently produce more efficiently. There are several reasons for this.

In contrast to the shareholders of private-sector firms who are largely united in the single objective of maximizing shareholder wealth, voters are rarely unanimous in their aims. Different voters are likely to place different values on the services that the government provides, so that A may prefer a cleaner environment, while $\mathrm{B}$ and $\mathrm{C}$ would like wider motorways. Not only do voters have divergent objectives, but there is no guarantee that a majority voting system will return a government that proposes to maximize the aggregate net benefits to all voters. For example, since B and C outnumber $\mathrm{A}$, their preferences would ensure the election of a government devoted to motorway construction, even though
$\mathrm{B}$ and $\mathrm{C}$ might have only a marginal preference for wider motorways, while A might be prepared to pay a large sum to preserve the environment. ${ }^{3}$ Furthermore, voters and therefore governments are concerned not only with maximizing net benefits but also with ensuring an equitable distribution of wealth. Thus, the ability of governments to stay in office depends on the trade-offs they make between efficiency and equity.

The disparate objectives of voters augment the discretion of governments and further their scope for self-serving behaviour. The agency problems that result are compounded by the different patterns of the distribution of voting power among shareholders and voters. In the case of private-sector firms, power is often highly concentrated among a small number of major claimholders, such as banks or large institutional shareholders, who have an incentive to monitor managerial performance. Moreover, this performance can be measured in terms of readily observable share prices. The shareholders of a firm can therefore compare its returns with those of other firms and make adjustments for systematic influences. Because shareholders have an observable and agreed measure of the firm's success, they can provide managers with highpowered incentives by linking remuneration directly to share-price performance. No such concentration of voting power exists in a democracy and no simple yardsticks are available with which to judge a government's performance. Indeed, the government's concern for equity adds to the difficulty of judging its efficiency. The resulting absence of a single observable performance measure makes it difficult in a democracy to offer high-powered incentives to members of the government. ${ }^{4}$

The severity of the agency problems encountered by the government may be compounded by the government's relative imperviousness to financial distress and its effective monopoly in the provision of many services. Unlike private-sector firms, the central government can often tax its way out of financial difficulties. The central government is therefore not unlike a firm that has large discretionary cash flows. These blunt the threat of financial distress and reduce its effectiveness in deterring

\footnotetext{
3 Arrow (1951) has formalized and extended this simple example to show the impossibility of a collective decision-making rule that satisfies a set of reasonable choice criteria.

${ }^{4}$ See Dixit (1996) for a discussion of incentives in government.
} 
wasteful investment in all but the most extreme cases (Jensen, 1986).

Finally, the absence of competition may be the primary reason for the public sector's lower efficiency. Such a conclusion is suggested by a number of studies that have found that, in those cases where competition exists, the efficiency of the public sector generally matches that of the private sector. ${ }^{5}$ There are several ways in which the lack of competition can compound agency problems within government. For example, Stiglitz (1989) suggests that the managers of government departments may engage in practices such as overmanning simply because they make a manager's task easier. The absence of competing organizations also precludes comparisons that would help assess the relative efficiency of the government and improve incentives. ${ }^{6}$

\section{(iii) The Reasons for Government Intervention in Economic Activity}

The preceding discussion suggests that the private sector may have some efficiency advantages over the public sector. The greater productive efficiency of the private sector need not, however, imply its greater allocative efficiency relative to the public sector. ${ }^{7}$ Attaining a Pareto-efficient allocation of resources in the absence of government intervention requires that $(a)$ all effects on welfare be traded in markets and $(b)$ these markets be perfectly competitive. It is, therefore, widely acknowledged that there are three broad cases in which allocative efficiency may be improved by government intervention (Rosen, 1995). These are (a) the case of public goods, (b) the case of monopoly power, and $(c)$ the case of externalities. The government's ability to intervene successfully in these cases stems from the fact that it is the one organization that has powers of compulsion over the whole citizenry. These reduce the cost of entering into multilateral contracts (Stiglitz, 1989).

\section{Public goods}

A public good is a good that, once provided to some initial consumers at some cost, can be enjoyed by additional consumers at no extra cost. Examples of public goods include the daily weather forecast, a lighthouse, a public park and national defence. ${ }^{8} \mathrm{~A}$ consumer then has an incentive to free-ride on the purchase of the good by other consumers. If every consumer were to attempt to engage in such freeriding, the good clearly would not be provided by the private sector for no consumer would pay for it. While the problem of a public good can sometimes be alleviated by excluding free-riders (for example, by fencing off a park), maximizing welfare requires that the price of the good be set equal to the marginal cost of providing it to an additional consumer, which equals zero for a public good. A private-sector firm with positive production costs would then have no incentive to supply the good. ${ }^{9}$ Some government intervention may therefore be needed in order to encourage the production of public goods.

\section{Monopolies}

Government intervention may also be needed in the case of natural monopolies, where relatively large fixed costs reduce marginal costs below average costs over the relevant ranges of output. Welfare maximization requires that price equals the marginal cost of production. However, no private-sector firm has an incentive to supply consumers at such a price. ${ }^{10}$ Thus, as in the case of a public good, output will generally be below its welfare-maximizing level. Even in the absence of a natural monopoly, in which case marginal costs exceed average costs, a firm that faces a demand schedule that is imperfectly elastic has an incentive to use its market power to hold output below its welfare-maximizing level.

${ }^{5}$ For comparisons of the efficiency of refuse collection by the public and private sectors, see Domberger et al. (1986) and Szymanski (1996) for the United Kingdom, and Kitchen (1976), Savas (1977), and Stevens (1978) for the United States.

6 Two further benefits of competition are to encourage innovation, and favour, through a process of natural selection, those innovations that reduce costs. A different form of competition occurs among local government entities. Tiebout (1956) argues that under some fairly restrictive conditions competition between local governments will attract agents with similar tastes, thus resulting in a Pareto-optimal output of public goods.

${ }^{7}$ Nor need it imply the absence of any productive inefficiency on the part of the private sector. See Rotemberg (1991) for an example.

${ }^{8}$ See Cornes and Sandler (1986), Oakland (1987), and Starrett (1988) for references on public goods.

9 A market solution to the public-good problem exists when each consumer can be induced to reveal truthfully the value he places on the good and to pre-contract with other consumers to pay that value, or when the firm providing the good is able to discriminate perfectly among consumers and to charge each consumer his valuation of the good. This is rarely the case in practice.

${ }^{10}$ A firm would, however, be willing to supply the good if it were able to discriminate perfectly among consumers in its pricing. As already noted, this is unlikely to be the case in practice. 


\section{Externalities}

Finally, government intervention may be needed in the presence of externalities. These occur when the actions of firms or consumers impose costs or confer benefits on third parties, which the firms or the consumers fail to take into account in choosing their actions. For example, a commuter who must choose between driving to work and taking the train will generally fail to take into account the added congestion that a decision to drive would impose on otherdrivers. Similarly, when choosing among alternative fuels, an electric utility may not take into account the environmental effects of these fuels, and, when undertaking risky trades, a bank may not take into account the systemic effects of its possible failure.

\section{(iv) The Forms of Government Intervention: Taxes, Subsidies, Regulation, and the Direct Provision of Services}

We have described three cases where market competition cannot be relied upon to allocate resources efficiently except under quite restrictive conditions. Some form of government intervention may therefore be required in order to achieve more efficient allocations. As noted in the introduction, such intervention need not take the form of the direct provision of services by the government, but may instead take the form of taxes, subsidies, or regulation. Consider, for example, the case of a public good, where the need for intervention arises from the incentive of a consumer to free-ride on the purchases of other consumers. The government, acting on behalf of society, can use its powers of taxation to overcome the free-rider problem. It can then directly provide the good to consumers or subsidize a private firm that provides the good on the government's behalf. In the case of a lighthouse, for example, the government may either operate the lighthouse itself or it may subsidize a private firm that does so on its behalf. ${ }^{11}$ In the latter case, the government may need to know the cost structure of the private firm. It needs to specify the quality of the service to be provided in a verifiable contract and to commit itself to a pricing scheme. The extent to which it is not possible for the government to do so, whether it be for a lighthouse, for as important a service as national defence, or for as mundane a service as the maintenance of flower beds in a public park, determines the desirability of having the government provide the service itself. ${ }^{12}$

Similar issues arise in the case of a natural monopoly, where the need for government intervention arises from the inability of a firm simultaneously to charge marginal cost and to recover its fixed costs. Again, government intervention need not take the form of the direct provision of services and the government may instead choose to subsidize the firm's fixed costs. However, such subsidies may not be feasible in the face of the aforementioned problems of asymmetric information and incomplete contracting or in the case of complex businesses that may divert the subsidies from their intended use. A second-best solution in such cases is to regulate prices such that the monopoly expects to earn only a competitive rate of return. Such regulation serves to increase firm output as compared with the case of a monopoly, but, because prices need to cover the firm's fixed costs, output none the less remains below its socially optimal level. Regulation also involves an inevitable trade-off between affording the monopoly the opportunity to exercise its monopoly power and providing it with the incentive to reduce costs. For example, a short regulatory lag reduces the opportunity for the regulated firm to exercise monopoly power, but simultaneously reduces its incentive to control costs.

Externalities exist because there are no markets in the relevant resources, whether these be clear roads, clean air, or safe financial systems. They are therefore not taken into account in firms' investment decisions or individuals' consumption decisions. The creation of the relevant markets and the allocation of property rights to the relevant resources may induce firms and consumers to take these into account in making their decisions (Coase, 1960). Thus, if an electric utility were required to buy the right to emit, say, sulphur oxides from those who would be affected by such emissions, the utility would take its emissions of sulphur oxides into account when making its choice of fuel. ${ }^{13}$ The presence of externalities may therefore require

\footnotetext{
11 Interestingly, although a lighthouse has been viewed as the archetypal public good, privately owned lighthouses operated in England and Wales until 1842 and were authorized to levy tolls at nearby ports. See Coase (1974) for a discussion.

12 For example, it is difficult to specify ex ante the desired quality of a flower bed or to verify expost whether a private contractor has met the required standards.

${ }^{13}$ This would also be the case if the utility were to sell its limitation of such emissions to those affected.
} 
government intervention to allocate the relevant property rights. An example of such intervention is the auction of pollution permits in the United States. If the quantity of pollution rights to be auctioned were set so as to equate the resulting price to the marginal damage from pollution at the efficient level of output, the auction would lead firms correctly to take into account the pollution they cause. ${ }^{14}$ Another solution is to use taxes or subsidies to make firms bear the costs or reap the benefits of externalities. For example, to ensure that a bank recognizes the systemic risks that its trading activities impose on the banking system, a regulatory body may choose to impose on the bank capital requirements that reflect the public costs of its trades. However, neither auctions nor taxes or subsidies can solve the problem of externalities where there is asymmetric information or incomplete contracting. Indeed, even the successful allocation of property rights may not be sufficient to solve the problem of externalities, for bargaining between parties may break down where there is asymmetric information (Myerson and Satterthwaite, 1983). Thus, the presence of externalities may require the direct provision of services by the government. ${ }^{15}$

Subsidies, taxes, and regulation therefore share a number of drawbacks as responses to the problems presented by public goods, monopoly and externalities. They require the government to be able to verify the quality of the firm's output and to have considerable information about a firm's cost structure, which the firm has obvious incentives not to reveal. Moreover, they reduce a firm's incentives to lower costs and they are exposed to opportunistic behaviour by the government and the firm. The government may attempt to expropriate the investments made by the firm and the firm may attempt to lower the quality of the services it provides or threaten to withhold them altogether. Where these drawbacks become sufficiently severe, the government may prefer the direct provision of services using government-owned assets. The benefits of government provision and ownership are similar to those of vertical integration. They provide the government with the right to gather information unimpeded, the right to set incentives for managers, and the residual rights of control. Government ownership clearly precludes expropriation by the government. ${ }^{16}$

It is important to note that government provision of services need not require government ownership of the assets used to provide these services. The government may instead choose to lease these assets. One determinant of the choice between ownership and leasing is the possibility that the government may expropriate the assets. Another is the extent to which the government should have control over the assets. Where control over the assets has few allocative consequences, the choice between owning and leasing should essentially be neutral. In contrast, where control over the assets has important allocative consequences, the government should own the assets.

To illustrate, consider the recent decision by the UK government to seek tenders from the private sector to build, own, and operate a new fleet of tank transporters. These would be used in the event of a war to transport tanks to war zones. ${ }^{17}$ Our analysis suggests that such a task may best be left to the government, which should own the assets the task requires. There are obvious difficulties in writing contracts with a private provider as to the appropriate behaviour in the heat of battle and a private owner may well be reluctant to risk damage to his assets by rough usage or by postponing mainte-

${ }^{14}$ See Sappington and Stiglitz (1987) on conditions for government auction of the right to produce to achieve efficiency, equity, and maximum rent extraction. These conditions are, however, subject to the aforementioned informational and contractual considerations.

15 The government may also attempt to address the problem of externalities by $(a)$ proscribing certain undesirable activities such as polluting or smoking in public places, $(b)$ allowing injured parties to sue for compensation, and $(c)$ requiring permission, such as planning consent to erect buildings which could have an impact on existing residents (a procedure which is likely to be most effective where there is a need to strike a balance between different externalities). Mergers constitute another solution to the problem of externalities, for a merger internalizes an externality. Consider, for example, a car manufacturer that properly recognizes the impact of its introduction of a new model on its existing product range, but fails to recognize its impact on the products of another car manufacturer. Such an externality would disappear were the two car manufacturers to merge, for they would then recognize the impact of the new model on both existing car ranges. Obviously, though, not all externalities can be internalized through mergers.

${ }_{16}$ See Grossman and Hart (1986), Hart and Moore (1990), Hart et al. (1997), Laffont and Tirole (1993), Riordan (1990), Schmidt (1996), and Williamson (1985).

${ }^{17}$ See the article 'Plan for Civilians to Drive Army Tanks to War Zones' by Ross Tieman, Financial Times, 3 September 1997. 
nance. To the extent that such considerations could affect the course and the outcome of a battle, they would clearly have important allocative consequences. $^{18}$

In summary, the public sector is likely to be less efficient than the private sector, because of its higher agency costs. However, productive efficiency need not imply allocative efficiency and there may be a case for government intervention in the economy. Such intervention may take the form of taxes, subsidies, or regulation, or the provision of services by the government using assets it has leased from the private sector, but all such forms of intervention suffer from some limitations, be they due to imperfect information, incomplete contracting, or distorted incentives. The direct provision of services by the government using governmentowned assets may be less exposed to these limitations, because of the rights to information and the control rights that are inherent in ownership. Thus, the decision to place an economic activity and the assets it requires in the public rather than the private sector involves a number of trade-offs, of which the most important is that between the greater productive efficiency of the private sector and the allocative efficiency that public provision and ownership may help achieve.

\section{CRITERIA FOR PUBLIC-SECTOR INVESTMENT}

We now examine the criteria for public-sector investment. We first note that these cannot be identical to those for private-sector investment for, as we have seen in section II, government intervention in the economy is motivated by the very limitations of the criteria for private-sector investment. Thus, the oft-called-for 'level-playing field' between the public and private sector should be neither possible nor desirable. The only cases where government assets should have the same value as their private-sector equivalents are those where, in addi- tion to there being no differential agency effects and no distortions such as taxes, there are no public goods, no monopolies, and no externalities. But these are the very cases in which there is no motive for public ownership.

Despite this presumption of a difference between public- and private-sector valuations, there are important dimensions along which valuation procedures should be the same in the two sectors. Differential agency effects, public goods, monopolies, and externalities affect only the cash flows of a project. As we shall argue below, the cost of capital is the same in the public and private sectors in the absence of tax distortions and with complete capital markets. Under such conditions, then, a given set of future cash flows with a particular level of risk should be valued in the same way in the public and private sectors. Our focus in this section is, therefore, on imperfections, such as taxes, that drive a wedge between the opportunity cost of capital in the public and private sectors. ${ }^{19}$

Prior to examining these, we briefly discuss the issue of unanimity among shareholders and citizens. The costs and benefits of a firm's investment decisions are shared proportionately by the firm's shareholders, who are therefore largely united in their objectives. Such proportional sharing is generally not true of public-sector investments. For example, the benefits of a new hospital or motorway will be enjoyed primarily by a small segment of the population, whereas the resulting tax burden will be borne by all taxpayers. Moreover, as we have seen in section II, government investments may be motivated by externalities, which affect different segments of the population in varying degrees. A rule that requires the government to make only Paretoimproving investments - that is, investments that make at least someone better off and no one worse off-is clearly too restrictive for practical use. An alternative rule, which was suggested by Hicks (1940) and Kaldor (1939), would require the government to value all the benefits and costs of

\footnotetext{
18 The government can, of course, requisition the tank transporters and probably will do so, but the expectation of such a course of action will essentially reduce the situation to one of government ownership.

19 This is not to deny the importance or the difficulty of quantifying future benefits and costs. The latter is compounded in the case of government investment by the need to identify all parties affected by such investment and by the lack of market prices for many benefits such investment provides. The difficulty of quantifying benefits may be such that the government takes these as given and concerns itself only with the minimization of costs. None the less, because these difficulties are common to all government projects as opposed to investment projects alone, they are somewhat beyond the scope of the present paper.
} 
proposed investments and make those investments that offer the largest net benefits.

Under the Hicks-Kaldor criterion, a project should be undertaken by the government if those who benefit from the project can afford to compensate those who suffer- that is, those who bear the direct costs of the investment or are exposed to its negative externalities. However, since such compensation may not always be paid, the government needs to recognize the distributional effects of the investments it makes. ${ }^{20}$ This may be achieved by postulating a social welfare function that summarizes the relative merits of alternative income distributions, but it is unclear how such a function should be determined. Moreover, it would clearly be suboptimal to take distributional considerations into account on a project-by-project basis. In the face of these difficulties, it is common simply to calculate the net benefits of an investment and to make a separate judgement as to its distributional consequences.

\section{(i) The Cost of Capital in the Public Sector}

The defining characteristic of investment decisions is their concern with benefits and costs that are not coincident. Costs are generally incurred at the outset, whereas benefits may be delayed. Future benefits and costs must be discounted to the present. An important issue in public finance is therefore the determination of the appropriate discount rate or cost of capital and its comparison with that used by private-sector firms. In discussing this issue, we first abstract from risk and taxes.

The opportunity cost to the government of investing in risk-free real assets is the reduction in interest payments that it would achieve if the cash to be invested were instead used to repurchase government debt. Since similar opportunities are open to private-sector firms, the rate of interest on government debt is the opportunity cost of capital for a riskfree investment by both the public and private sectors.
Notwithstanding the above argument, it has been argued that the discount rate used by the government, the social rate of time preference or social discount rate, should differ from the market rate of interest. ${ }^{21}$ Thus, HM Treasury (1997) makes the following conceptual distinction between the market rate of interest and the social discount rate:

(i) Resource expenditure by government has an opportunity cost, because the resources would otherwise be available for other uses, to provide immediate consumption benefits and be at least partly invested to produce a return. There is a further cost of the distortions caused by taxation, at the margin, to fund increments in public expenditure.

(ii) These opportunity costs apply equally to extra expenditure and to expenditure savings, and, in general, apply as much to later as to earlier years. They are therefore generally not relevant to the simple comparison of public expenditures over time, for which the conceptual basis depends on people's time preference for consumption.

It is unclear what is the appropriate decision rule if the two rates point to different courses of action or how the choice of rate depends on the nature of the flows. In the event, the Treasury sidesteps these issues by concluding that the difference between the two rates is unlikely to be large enough to justify making a practical distinction. Its decision to use a discount rate of 6 per cent for public-sector projects is explained as follows:

The practical choice of 6 per cent, from the top of the range, for the cost of capital and the time preference rate, is an operational judgement, reflecting, for example, concern to ensure that there is no inefficient bias against private-sector supply.

There may be several motives for wishing to distinguish between the opportunity cost of capital and the social discount rate. Individuals may be myopic grasshoppers, intent on immediate consumption and careless of the need to save for the winter of old age. ${ }^{22} \mathrm{~A}$ benevolent government may then be justi-

\footnotetext{
${ }^{20}$ For example, suppose that the government wishes to undo the redistributive effects of a new motorway by taxing its beneficiaries and using the proceeds from the tax to recover the costs of constructing the motorway and compensate those it has adversely affected. If the government can identify these beneficiaries only through their use of the motorway and therefore taxes usage of the motorway, usage is likely to be suboptimal.

${ }^{21}$ See Pearce and Nash (1981) for a reference on the social rate of time preference.

${ }^{22}$ Pigou (1932) refers to such myopia as 'defective telescopic faculty'.
} 
fied in encouraging investment for the future and may even want to invest in projects that have a lower return than that required by investors. Perhaps more rationally, individuals may fail to consider the welfare of future generations in making their consumption and investment decisions. ${ }^{23}$ The government, acting as the guardian of future generations, should therefore be prepared to invest at rates of return that individuals acting in their own selfish interest would find unacceptable. ${ }^{24}$

To the extent that it involves a value judgement about the sacrifice that one generation ought to make on behalf of another, the social rate of time preference cannot be a matter for economic analysis. But it is not even clear that, in principle, a democratically elected government could or should use any discount rate but the market rate of interest to value its investment. Thus:

- The argument for a social rate of time preference that favours investment begs the question of how hedonistic or selfish individuals will come to elect a government that can then be relied upon both to ignore their wishes and to act in 'society's best interests'.

- The argument that society will under-invest if left to itself is an argument for increased private as well as government investment. The appropriate response to such under-investment may therefore be to discriminate in favour of savings and against consumption, perhaps through taxes and subsidies. The use of a social discount rate that is lower than the market rate of interest may therefore address the symptoms rather than the causes of the under-investment problem.

- The prevalence of bequests suggests that present generations do, in fact, care about future generations. There should therefore be no under-investment problem (Weil, 1987).
The previous arguments notwithstanding, a government would be justified in using a discount rate that is lower than the market rate of interest only when the resources to be invested by the government cannot be invested at the market rate of interest. When these resources can be invested at the market rate of interest, whether by the private sector or the public sector, it is clearly undesirable to divert them to an investment that will return the lower social discount rate. The preceding observation suggests that the issue of distinguishing between the market rate of interest and the social discount rate arises only in the case of a large project in a large economy, for such a project may affect the market rate of interest. In the case of a small, open economy, as are most economies today with the possible exception of the United States and Japan, resources can always be invested at the world market interest rate. The social discount rate, therefore, cannot be lower than the market interest rate, for it is the latter that represents the opportunity cost of any investment.

\section{(ii) The Opportunity Cost of Capital and the Required Rate of Return}

In addition to making a conceptual distinction between the social discount rate and the opportunity cost of capital, the UK government also distinguishes between the opportunity cost of capital and the real required average rate of return (RRR), which is used as the discount rate for investment in trading activities. The distinction between the opportunity cost of capital and the RRR is explained as follows (HM Treasury, 1997):

For output sold commercially to the private-sector prices should generally be set to obtain a higher average return. This reflects the fact that average returns in the economy as a whole appear to be higher than marginal returns, which could arise from producers' increasing returns to scale or from less than perfect competition. A value of no less than 8 per cent should normally be expected for commercial sales by public services to the private sector.

${ }^{23}$ Older generations will, of course, capitalize on their investments by selling these to younger generations. Such trade may none the less fail to lead to an efficient solution because a given generation will ignore the externality constituted by the effect of its investment on the wealth of the succeeding generation. There is no market for this externality, for the succeeding generation is not yet born when the present generation invests (Diamond, 1965).

${ }^{24}$ A different argument for distinguishing between capital market rates and the social discount rate relies on imperfections in the capital market. For example, Mishan (1980, p. 287) writes: 'For, as a result of rationing the amount of money lent to each borrower, the rate of interest he pays on the marginal dollar borrowed may be well above his rate of time preference. For more reliable estimates of people's time preferences then we have to go beyond market data.' Similar arguments are cited in Spackman (no date). While such imperfections may well exist in developing countries, they are unlikely to exist in developed countries. 
It is difficult to understand the rationale for this distinction. It is clearly true that, if private-sector firms undertake only those projects that have positive NPV when valued at the cost of capital, the average rate of return will be higher than the cost of capital. But private-sector firms do not in consequence change their criterion to one of earning an above-average rate of return. ${ }^{25}$ If governments follow a policy of accepting only those projects that are expected to earn at least the cost of capital, they too will find that their average return exceeds the cost of capital.

The RRR no longer appears to play a major role in investment decisions by the UK government and our focus below is, therefore, on the correct definition of the opportunity cost of capital for publicsector investments.

\section{(iii) Taxes and Public-sector Investment}

The preceding discussion has abstracted from both taxes and risk. We now introduce taxes, but still abstract from risk. In the absence of risk, a privatesector firm can finance a project entirely with riskfree debt. The firm will choose to do so in the presence of a tax advantage to debt. ${ }^{26}$ Since interest payments on debt are tax-deductible by the firm, the cost of debt is reduced from the pre-tax interest rate payable on the debt to the after-tax interest rate that measures the actual cash outflow from the firm. ${ }^{27}$ The after-tax interest rate is the rate at which firms can risklessly transfer money backward in time by borrowing. It is also the rate at which firms can transfer money forward in time by lending. It is therefore the opportunity cost of capital for risk-free investments by private-sector firms. ${ }^{28}$

Initially, consider the case of a private-sector firm that seeks to maximize shareholder wealth. Taxes are simply a cost of production to such a firm and must therefore be deducted from the cash flows that are to be discounted. Taxes also need to be accounted for in the rate at which the cash flows are discounted. As argued above, this rate is the aftertax interest rate.

Now consider the case of the government. Since taxes accrue to the government, they clearly should be deducted neither from cash flows nor from the interest rate. The cash flows discounted by the government are therefore pre-tax cash flows and the rate used to discount these cash flows is the pretax interest rate. This is the total return earned by the treasury and the tax authorities from an investment in risk-free debt.

The view that the pre-tax interest rate is the cost of capital for risk-free investments by the public sector was put forward by Baumol (1968). However, others have argued for a weighted average of pretax rates and after-tax rates. Sandmo and Drèze (1971) assume that firms are financed solely by equity and (implicitly) that there are no personal taxes. In this case, because of the failure to exploit the tax advantage of debt, firms require a return after payment of corporate tax of the pre-tax interest rate $r$ as opposed to the after-tax interest rate $(1-t) r$. Firms, therefore, require a return before payment of corporate tax of the grossed-up interest rate $r /(1-t)$. Since the marginal rate of substitution between current and future consumption faced by individuals is the pre-tax interest rate, $r$, corporation tax drives a wedge between the rate faced by consumers, $r$, and the tax-distorted rate faced by firms, $r /(1-t)$. Sandmo and Drèze argue that the correct discount rate for the government is therefore a weighted average of $r$ and $r /(1-t)$, where the weight on the grossed-up interest rate is equal to the proportion of the funds that would otherwise be invested by the private sector.

Harberger (1968) employs a similar argument in which firms investing in risk-free projects require a pre-tax rate of return equal to the grossed-up interest rate $r /(1-t)$. Individuals pay tax on investment income of $t_{p}$ and therefore their marginal rate of substitution between consumption and investment is

\footnotetext{
${ }^{25}$ Indeed, a policy of accepting only investments that are expected to earn an above-average return would ultimately lead to zero investment.

${ }^{26}$ The tax advantage to debt exists only in a Modigliani and Miller (1963) equilibrium. In a Miller (1977) equilibrium, firms are indifferent between debt and equity and their cost of capital is the after-tax interest rate regardless of the form of financing they choose.

${ }^{27}$ Thus, if the pre-tax interest rate is denoted $r$ and the corporate tax rate is denoted $t$, the after-tax interest rate is $(1-t) r$.

${ }^{28}$ See Ruback (1986) for a formal proof.
} 
the interest rate after personal tax $\left(1-t_{p}\right) r$. Harberger therefore argues that the cost of capital for the public sector is an average of the grossed-up interest rate and the interest rate after personal tax.

The analyses of Drèze and Sandmo and of Harberger differ from ours both by their assumption that firms must earn the grossed-up interest rate on risk-free investments before payment of corporate tax and by their view that government projects displace private investment and consumption. The former argument ignores the ability of firms to finance risk-free investment by debt, in which case their required rate of return before corporate tax is the pre-tax interest rate, $r$. The latter argument may be valid in the case of a closed economy, but is unlikely to be valid in the case of a small, open economy. In the latter case, a government can always raise the funds it needs from world capital markets at the pre-tax interest rate required by investors. It need not divert any funds away from firms or consumers.

The above discussion suggests that the government should discount pre-tax cash flows at the pre-tax interest rate, whereas the private sector should discount after-tax flows at the after-tax interest rate. These two rules will sometimes lead to the same conclusions, as when taxes are a constant proportion of cash flows and these are perpetual. The two rules will, however, generally lead to different conclusions. The private sector will therefore be induced to follow tax-minimizing strategies which the government will appropriately ignore. There will then be the danger that the government may be led to devolve particular activities to the private sector simply because the private sector's incentive to minimize taxes allows it to price at levels that the government cannot match. ${ }^{29}$

The difference between the investment rules of the public and private sectors poses difficulties when the government wishes to compare the relative costs of public- and private-sector provision of a given service. It is clearly not appropriate to compare the price quoted by the private sector for the service to the government's assessment of the present value of the costs of public provision for, as noted above, the private sector's price may reflect its ability to minimize taxes. Similarly, when comparing two private-sector tenders to provide a service, the government should be concerned not simply with the relative prices quoted but also with the indirect effects on its tax take. While the information requirements of such comparisons can be onerous, the government needs to be aware that tax rules may be such that the apparent savings from transferring a given activity to the public sector are more than offset by lower tax receipts.

\section{(iv) Risk and the Cost of Capital for the Public Sector}

Our discussion of discount rates has so far ignored the issue of risk. The choice by many governments and multilateral institutions of discount rates that are close to the risk-free rate suggests that they view public-sector projects as being of low risk. It is not entirely clear, however, whether this is because governments view the projects undertaken by the public sector as being by nature of low risk or whether it is because they consider that projects become of low risk by virtue of being undertaken by the public sector. We discuss these issues in what follows.

A common but naïve case for using a low publicsector discount rate focuses on the fact that the government can borrow at the risk-free interest rate. Private-sector firms generally borrow at a higher rate of interest than does the government and, more importantly, must service equity made costly by the risk premium that must be paid to shareholders. The apparent contrast between cheap debt raised by the government and costly debt and equity raised by private-sector firms is, however, misleading. Taxpayers bear the residual risk of government investment, particularly that of making good on the obligations to debtholders, in much the same way as the shareholders of a private-sector firm. ${ }^{30}$

\footnotetext{
${ }^{29}$ Conversely, there will be the danger that the government, which does not pay indirect taxes, such as value-added tax or excise duties, may enter, say, the brewing business simply because its does not treat such taxes as a cash outflow.

${ }^{30}$ Taxpayers arguably bear more risk than do shareholders, for shareholders are protected by limited liability in a way that taxpayers are not. On the other hand, shareholders do not partake in the central government's unique ability to print money to pay off bondholders.
} 
A more sophisticated argument for a low public discount rate has been made by Arrow $(1965,1966)$, Arrow and Lind (1970), Samuelson (1964), Solow (1965), and Vickrey (1964). As noted by Bailey and Jensen (1972), underlying this argument is the presumption that $(a)$ the risk of public-sector projects is distributed over the entire population, (b) diversifying risks through government ownership can serve to eliminate risk to a very large extent, and $(c)$ such diversification can be achieved more cheaply by the government than by financial markets. ${ }^{31}$ Thus, Vickrey states:

But insofar as riskiness is concerned, the reason risky investments carry an expected return greater than that of secure investments is that in the market facilities for pooling of risks are imperfect, so that investment by private investors in risky investments, given a limited portfolio and a certain indivisibility in the market, is unavoidably associated with a considerable dispersion of individual incomes.... On the social level, however, the risk associated with a given public venture is inevitably pooled and averaged over the entire population of the country in some fashion, along with the risk of other projects, and this pooling or averaging of risks for public projects is accomplished without any cost of extra financial transactions.

Critics of these risk-pooling arguments include Hirshleifer(1964), Diamond (1967), and Bailey and Jensen (1972). Their arguments are directed against each of the argument's three headings.

(a) While it is true that much of the uncertainty about the costs of a government project is borne by taxpayers and is, therefore, widely distributed, the uncertainty about the project's benefits is generally borne by the specific individuals who receive those benefits. For example, a new motorway is likely to be used by a relatively small proportion of the population and it is this limited group that bears all the uncertainty about the benefits of the motorway. ${ }^{32}$

(b) Pooling can eliminate risk only if the outcomes of public projects are independent both of each other and of outcomes of private investments. While
Arrow and Lind recognize the former condition, they provide no evidence that it is satisfied. On the empirical issue of whether outcomes are positively correlated, Bailey and Jensen comment:

[S]ome brief consideration of the problem seems to indicate (contrary to Samuelson et al.) that the vast majority of government projects will have outcomes correlated with national income. For instance, any government investments will produce more benefits when national income is high than when it is low. Electric power, highways, waterways, airports, and postal services, for example, all have this character.

(c) The assertion that private markets do not constitute an efficient mechanism for insuring risk is not justified. Diamond takes issue with the assertion as follows:

By means of portfolio diversification on the part of consumers, all of the economies averaging possibilities are brought to bear on each production decision. Thus ... large firms have no pooling advantages over private business. Provided that the government does not go outside the linearity constraints of the model, government investors would imitate private business, evaluating individual projects separately, not pooling, and looking to the stock market for the appropriate returns criteria.

Perhaps the determining consideration is this (Hirshleifer, 1964; Bailey and Jensen, 1972): in the presence of complete capital markets, in which the pay-offs to all projects are spanned by existing securities, taxpayers can shed any risk that accrues from the undertaking of a project by the government by trading in the capital markets. The risk premium demanded by the capital markets is the cost of shedding this risk. It is therefore the risk premium demanded for both public- and private-sector projects. ${ }^{33}$

\section{(v) The Use of a Common Discount Rate for Public-sector Projects}

As noted above, the UK government employs the same discount rate of 6 per cent across the vast majority of public-sector projects. Yet, it is widely

\footnotetext{
${ }^{31}$ In their discussion of the discount rates used by the UK government, Pearce and Nash (1981) appeal to the risk-spreading argument of Arrow and Lind to justify the use of a low rate. However, the discussion of risk in Spackman (no date) suggests that the government's choice of a low rate does not rely on any unique ability of the government to spread risk, but stems from the view that many of its projects are inherently of low risk and would be viewed as such even if they were undertaken by the private sector.

${ }^{32}$ We might also note that the externalities, which are often used to justify investment by the public sector, may also affect only a limited sector of the community.

${ }^{33}$ See Klein's article in this issue for a further discussion of the public sector's cost of capital.
} 
accepted that the discount rate should vary with a project's exposure to factor risk. While fine distinctions regarding project risk may not be feasible, there is a danger that, when assets are exchanged between the public and private sectors, spurious apparent value may be created by the use of an inappropriate discount rate. This is particularly important in the case of those asset transactions that are effectively financing transactions. For example, the sale and leaseback of government property, a type of transaction that has become quite widespread in the UK recently, should be evaluated using a lower required rate of return than a typical publicsector project, because it generally has a very low level of risk.

For many government projects, sponsors are concerned with the maximization of net benefits - that is, benefits less associated costs. For some projects, however, benefits are taken as given and sponsors are concerned only with the minimization of costs. If these costs contain a sizeable fixed element, they may be somewhat less risky than benefits, and substantially less risky than net benefits. While we cannot observe separate market prices for the revenue and cost streams of private-sector firms, it is possible to estimate the co-variance of changes in these firms' revenues and costs with changes in aggregate accounting profits. These co-variances can be used to derive 'accounting betas' that serve as proxies for the systematic risks of the revenue and cost streams. Preliminary estimates of these accounting betas for a sample of UK firms suggest that the beta of after-tax profits is about ten times that of revenues and twenty times that of trading expenses. Although these estimates have substantial standard errors, they nevertheless suggest that the average discount rate for costs should be little more than the risk-free rate of interest.

The case for using a relatively low discount rate to value a stream of costs relies on the fixed nature of many costs. This is distinct from the common misconception that, when calculating present values, the adjustment for risk should depend on the sign of the cash flow. Thus, Stiglitz (1988, p. 270) argues:

To see how increasing the discount rate [to account for risk] may lead to absurd results, consider a project that, at termination, requires an expenditure (an automobile has to be towed to the junk yard). Assume that there is some uncertainty about the magnitude of that cost. We would normally think that this uncertainty would make that project less attractive than if we knew for sure what the termination costs were. But consider what happens if we use a higher discount factor to offset the risk: the present value of those costs is reduced, and the project looks more, not less, attractive.

Stiglitz goes on to argue that the certainty equivalent value of the termination cost is higher than the cost itself.

This argument is misleading. There is nothing absurd in the notion that a liability is less onerous if it results in larger outflows when aggregate wealth is high and lower outflows when aggregate wealth is low. A liability that co-varies with the value of the market portfolio is rightly preferred by risk-averse investors to one that is fixed, come-hell-or-highwater. To vary the discount rate or certainty equivalent adjustment according to the sign of the cash flows would have unfortunate consequences. For example, it would imply unlimited arbitrage opportunities, for the buyer of any asset who looks forward to positive cash flows would always place a different value on that asset than the seller who faces negative future cash flows. Moreover, the sum of the values of a positive and a negative cash flow would differ from the value of the sum of the two cash flows.

\section{(vi) Separation of Investment and Financing}

Another important feature of private-sector investment appraisal that applies equally to governments is that the evaluation of an investment should, in general, be independent of the financing of the investment. It should also be independent of the accounting treatment of the investment and its associated financing. For example, as we have already noted, the fact that the government finances its investments by borrowing at a lower rate than the private sector is irrelevant to the evaluation of its investments as this low borrowing rate is made possible only by the government's powers of taxation and is unaffected by the projects that it invests in. Similarly a government transaction that happens to increase the public-sector borrowing requirement (PSBR) should not, in principle, be treated differently from another transaction that does not affect the PSBR. 


\section{(vii) Examples of Applications}

We conclude our discussion of public-sector investment appraisal with a brief discussion of two examples that highlight some of the issues considered above. The first, investment in general purpose property, is a case where the special features that make public-sector investment appraisal problematic are largely absent. The public sector's valuation of general purpose property should therefore largely duplicate the private sector's. The second example, prisons, is a case where the manner in which the assets involved are managed cannot be specified ex ante. Direct use is therefore required. Furthermore, if the private sector actually owns the assets, it may be difficult for the government to implement changes in, say, sentencing policy. This can have important allocative consequences.

The first example we consider is that of general purpose property, such as the many office buildings used by the public sector. Should these be owned and maintained by the public sector or should they simply be rented? To put the question differently, should the public sector's valuation of these assets be different from their private-sector valuation? In answering this question, we consider the various effects that may give rise to a difference between public- and private-sector valuations: public goods, monopoly power, externalities, agency effects, risk, and taxes. In the absence of any differential effect across the two sectors, public-sector valuation should simply follow the best practice in private-sector valuation.

In the case of general purpose property, such as an office building, it is hard to argue that there are any significant public goods, monopolies, or externalities. Agency effects that may result in less-efficient management of the property will be reflected in the estimated cash flows from the property. The discount rate used for valuation will not be affected by the existence of these effects. In so far as risk is concerned, risk sharing should be the same whether the asset is owned by the private sector or by the government, as the existence of a claim on a given property will do very little to complete the market. This leaves the final issue of taxes. If the public sector decides to own the property, rather than lease it, the present value of the lease payments thus saved must be compared to the purchase price of the property. This calculation should be carried out by discounting pre-tax cash flows at the appropriate pre-tax discount rate. In the hands of the private sector, however, the relevant calculation involves the discounting of after-tax cash flows at the aftertax opportunity cost of capital. As a result, the private sector may value the asset more highly than the public sector if, for instance, the private sector can use the asset to reduce taxes. The private sector may therefore be willing to pay more for the asset than the public sector by the present value of the tax savings it can achieve by owning the asset. This should not necessarily constitute a reason for the government to sell the asset to the private sector, however, for it is taxpayers who will pay for this apparent gain.

The second example is that of prisons. It is clear that, through their contribution to the maintenance of law and order, prisons provide a public good. Prison services should therefore be financed by the government. The provision of such services can, however, take many forms: the government may subsidize private prisons, it may manage prisons leased from the private sector, or it may manage prisons that it owns. As noted by Hart et al. (1997), the government may need to manage prisons itself to the extent that the quality of prison services is not contractable and that private prison operators have an incentive to under-supply quality in order to minimize costs. ${ }^{34}$ This does not imply that the government should own the prisons, however, for the government may lease prisons that were built and are owned by the private sector. The need for government ownership of prisons arises from two considerations. The first is that the government is, in a sense, a monopoly supplier of inmates. Private prisons therefore suffer from the classic hold-up problem (Williamson, 1985). The government may try to appropriate private prison owners' quasirents, for example by threatening a more lenient incarceration policy that would decrease the supply of inmates. In such a case, unless it is possible to write long-term contracts whereby the government would commit itself to a given occupancy level, private-sector suppliers would be reluctant to own private prisons.

\footnotetext{
${ }^{34}$ For a contrary view, see Domberger and Jensen in this issue.
} 
The second consideration is related to the allocative consequences of the reliance on private prisons. A decision by the government to change its sentencing policies, for example by introducing mandatory sentencing laws, would require private prison operators to accede to the government's desire for increasing the capacity of existing prisons, at least until new prisons have been built. The ability of the owners of private prisons to drive a hard bargain with the government, for example by threatening to deny the government the desired increase in capacity, may then deter the government from engaging in such a policy if the cost of obtaining the owners' approval were viewed as prohibitively expensive by a cashconstrained government.

\section{CONCLUSION}

In section II we discussed the distinctive features of government intervention in the economy. We suggested that governments are less well equipped than the private sector to handle agency problems and that this is likely to result in the lower productive efficiency of the government. We noted, however, that there are three cases in which government intervention may be needed to improve allocative efficiency-namely, the cases of public goods, monopolies, and externalities. Such intervention need not take the form of the direct provision of services and outright ownership of the assets used to provide these services, but can occur through taxes, subsidies, and regulation. Provision and ownership give the government the right to gather information unimpeded, the right to set incentives for managers, and residual rights of control. These may be important in the presence of informational asymmetries and incomplete contracting. The fact that the case for public ownership is strongest when the government needs to address issues of allocative efficiency implies that it is neither possible nor desirable to attempt simultaneously to create a level playing field with the private sector.

In section III we discussed investment criteria within public-sector enterprises with particular emphasis on the cost of capital. In particular we argued that:

- in an open economy the relevant discount rate for government projects is the opportunity cost of capital - that is, the expected return on comparable investments in the capital markets;

- since the government receives all tax revenues, risk-free projects should be valued by discounting their pre-tax cash flows by the pre-tax interest rate;

- if the pay-offs to the project are spanned by existing traded securities, then the risk premium demanded should be the same in both the public and private sectors; the presence of complete capital markets lessens the need for the government to diversify on behalf of citizens;

- the appropriate discount rate for costs is generally substantially lower than for net cash flows.

\section{REFERENCES}

Arrow, K. (1951), Social Choice and Individual Values, New York, NY, John Wiley \& Sons.

- (1965), 'Criteria for Social Investment', Water Resources Research, 1, 1-8.

- (1966), 'Discounting and Public Investment Criteria', in A. V. Kneese and S. C. Smith (eds), Water Research, Baltimore, MD, Johns Hopkins University Press.

- Lind, R. C. (1970), 'Uncertainty and the Evaluation of Public Investment Decisions', American Economic Review, 60, 364-78.

Bailey, M. J., and Jensen, M. C. (1972), 'Risk and the Discount Rate for Public Investment', in M. C. Jensen (ed.), Studies in the Theory of Capital Markets, New York, NY, Frederick A. Praeger.

Baumol, W. J. (1968), 'On the Social Rate of Discount', American Economic Review, 58, 788-802.

Coase, R. (1960), 'The Problem of Social Cost', Journal of Law and Economics, 1-44.

- (1974), 'The Lighthouse in Economics', Journal of Law and Economics, 357-76.

Cornes, R., and Sandler, T. (1986), The Theory of Externalities, Public Goods, and Club Goods, Cambridge, Cambridge University Press. 
Diamond, P. A. (1965), 'National Debt in a Neoclassical Growth Model', American Economic Review, 55, $1126-50$. (1967), 'The Role of a Stock Market in a General Equilibrium Model with Technological Uncertainty', American Economic Review, 57, 759-76.

Dixit, A. K. (1996), The Making of Economic Policy, Cambridge, MA, MIT Press.

Domberger, S., Meadowcroft, S., and Thompson, D. (1986), 'Competitive Tendering andEfficiency: the Case of Refuse Collection', Fiscal Studies, 7, 69-89.

Grossman, S. J., and Hart, O. D. (1986), 'The Costs and Benefits of Ownership', Journal of Political Economy, 94, 691719.

Harberger, A. C. (1968), 'On Measuring the Social Opportunity Cost of Public Funds', in Proceedings of the Committee on Water Resources and Economic Development of the West; The Discount Rate in Public Investment Evaluation, Denver, CO, Western Agricultural Economics Research Council.

Hart, O. D., and Moore, J. (1990), 'Property Rights and the Nature of the Firm', Journal of Political Economy, 98, 111958.

- Schleifer, A., and Vishny, R. W. (1997), 'The Proper Scope of Government: Theory and an Application to Prisons', Quarterly Journal of Economics, forthcoming.

Hicks, J. R. (1940), 'The Valuation of the Social Income', Economica, 105-24.

Hirshleifer, J. (1964), 'Efficient Allocation of Capital in an Uncertain World', American Economic Review, 54, 77-85.

HMTreasury (1997), 'Economic Appraisal in Central Government: A Technical Guide for Government Departments', London, HMSO.

Jensen, M. C. (1986), 'The Agency Costs of Free Cash Flow, Corporate Finance and Takeovers', American Economic Review, 76, 323-9.

Kaldor, N. (1939), 'Welfare Propositions of Economists and Interpersonal Comparisons of Utility', The Economic Journal, 549-52.

Kitchen, H. M. (1976), ‘A Statistical Estimation of an Operating Cost Function for Municipal Refuse Collection', Public Finance Quarterly, 4, 56-76.

Laffont J.-J., and Tirole, J. (1993), A Theory of Incentives in Procurement and Regulation, Cambridge, MA, MIT Press. Miller, M. H. (1977), 'Debt and Taxes', Journal of Finance, 32, 261-76.

Modigliani, F., and Miller M. H. (1963), 'Corporate Income Taxes and the Cost of Capital: A Correction', American Economic Review, 53, 433-43.

Mishan, E. J. (1980), Cost-Benefit Analysis, London, Unwin Hyman.

Myerson, R. B., and Satterthwaite, M. A. (1983), 'Efficient Mechanisms for Bilateral Trading', Journal of Economic Theory, 29, 265-81.

Oakland, W. H. (1987), 'Theory of Public Goods', Handbook of Public Economics, Vol. II, London, North Holland, Amsterdam.

Pearce, D. W., and Nash, C. A. (1981), The Social Appraisal of Projects: A Text in Cost-Benefit Analysis, London, Macmillan.

Pigou, A. C. (1932), The Economics of Welfare, New York, NY, Macmillan.

Riordan, M. H. (1990), 'What is Vertical Integration', in M. Aoki, B. Gustafsson, and O. E. Williamson (eds), The Firm as a Nexus of Treaties, London, Sage.

Rosen, H. (1995), Public Finance, New York, NY, Irwin.

Rotemberg, J. (1991), 'A Theory of Inefficient Intrafirm Transactions’, American Economic Review, 81, 191-209.

Ruback, R. S. (1986), 'Calculating the Market Value of Risk-Free Cash Flows', Journal of Financial Economics, 15, 323-39.

Samuelson, P. A. (1964), 'Principles of Efficiency: Discussion', American Economic Review, 54, 93-6.

Sandmo, A., and Drèze, J.H. (1971), 'Discount Rates for Public Investment in Closed and Open Economies', Economica, 38, 395-412.

Sappington, D., and Stiglitz, J. E. (1987), 'Privatization, Information, and Incentives', Journal of Policy Analysis and Management, 6, 567-82.

Savas, E. S. (1977), 'Policy Analysis for Local Government: Public versus Private Refuse Collection', Policy Analysis, 3,49-74.

Schmidt, K. M. (1996), 'The Costs and Benefits of Privatization: An Incomplete Contracts Approach', Journal of Law, Economics, and Organization, 12, 1-24.

Solow, R. M. (1965), Capital Theory and the Rate of Return, Chicago, IL, Rand McNally.

Spackman, M. (no date), 'Discount Rates and Rates of Return in the Public Sector: Economic Issues', Government Economic Service Working Paper No. 113, HM Treasury. 
Starrett, D. A. (1988), Foundations of Public Economics, Cambridge, Cambridge University Press.

Stevens, B. J. (1978), 'Scale, Market Structure, and the Cost of Refuse Collection', Review of Economics and Statistics, 6,438-48.

Stiglitz, J. E. (1988), Economics of the Public Sector, London, W. W. Norton \& Co.

- (1989), The Economic Role of the State, Oxford, Basil Blackwell.

Szymanski, S. (1996), 'The Impact of Competitive Tendering on Refuse Collection Services', Fiscal Studies, 17, 1-19.

Tiebout, C. (1956), 'A Pure Theory of Local Expenditures', Journal of Political Economy, 64, 416-24

Vickrey, W. (1964), 'Principles of Efficiency: Discussion', American Economic Review, 54, 88-92.

Weil, P. (1987), 'Love Thy Children: Reflections on the Barro Debt Neutrality Theorem', Journal of Monetary Economics, 19, 183-98.

Williamson, O. E. (1985), The Economic Institutions of Capitalism: Firms, Markets, Relational Contracting, New York, NY, The Free Press. 